821.111(71).09-31

$791(71)$

https://doi.org/10.18485/bells.2021.13.10

\author{
Vera Nikolić" \\ Faculty of Philology \\ University of Belgrade \\ Belgrade, Serbia
}

\title{
MAPPING MEMORY AND DESIRE IN THE ENGLISH PATIENT: A POSTMODERN NOVEL'S ADAPTATION TO FILM
}

\begin{abstract}
The exploration of the adaptation of Michael Ondaatje's postmodern Canadian novel, The English Patient, into Anthony Minghella's film of the same name, is based on a postmodern approach to the theory of adaptation that distances itself from the fidelity critique in and dualistic approach to adaptations and views them as instances of intertextual dialogism. Additionally, the postmodern approach that is developed by Peter Brooker and Gordon Slethaug implements ideas of supplementation and surplus value to adaptations and indicates how meaning can be broken down and destabilized. The paper investigates the traits of the postmodern Canadian novel, such as historiographic metafiction and fragmentation, while also analyzing the novel The English Patient and the film The English Patient. Namely, the novel's narrative organization according to the dynamics of memory and the film's exploration of transgressive desires are presented, thus creating a detailed analysis of the adaptation of Ondaatje's novel into a new cinematic work.
\end{abstract}

Key words: film adaptation, supplementation, surplus value, postmodern Canadian novel, adaptation of a postmodern novel

E-mail address: nikolic.veran@gmail.com 


\section{Introduction}

Adaptation theories originated from a practice of determining the faithfulness of texts, particularly the faithfulness of films to the original texts that served as their basis. However, due to films and literature being "different rhetorical, semiotic, technical, and cultural forms of expression" (Slethaug 2014: 34), faithfulness did not hold up as an effective measure of the successfulness of adaptations. Concepts indicating the "transcendental meaning of language, literature, and film" allowed for the dissolution of an approach to adaptations that was rooted in fixedness and faithfulness and instead upheld an approach recognizing the diversity of relations between texts (Slethaug 2014: 34). The significance of the evolution of the approach to adaptation that stems from a postmodern perspective is highlighted by Gordon Slethaug: "[I]ntertextuality goes well beyond linking a single text to its origin, but allows for the complete range of textual relationships within culture, resulting in historical discontinuity, indeterminacy, decanonization, and fragmentation" (2014: 73). Slethaug further asserts the possibilities enabled by moving away from a traditional approach to adaptations: "[b]ecause of the history of adaptation criticism, there is the temptation to judge films on the basis of likeness in content, style, and meaning between filiated texts, but intertextuality is more about innovative and revolutionary ways of perceiving textuality, cultural matrices, and emergent meaning" (2014: 74).

This postmodern approach to adaptations allows for a more pertinent and effective consideration of the adaptation of postmodernist texts that are intrinsically characterized by fragmentation, temporal disorder and a disdain for historical continuity, traits that are also found in postmodern Canadian fiction, which is further realized in the works of historiographic metafiction, a form that incorporates self-reflexive art and historical reality. An approach to adaptations based on the understanding of the free play and indeterminacy of meaning and negation of fixedness and faithfulness, serves as a beneficial basis for the deliberation of the complexity and richness of the adaptation of the postmodern Canadian novel, The English Patient, which transposes Ondaatje's fragmentary narrative into a film. The central dynamic of memory in the novel is transformed in the film that explores how the characters transferred from Ondaatje's novel realize transgressive desires. The postcolonial themes of the novel are transformed into the film's counter-nationalist themes. By establishing visual equivalents of Ondaatje's 
Vera Nikolić: Mapping Memory and Desire in The English Patient: A Postmodern Novel's...

narration, as well as inventing new aspects of the story in the film, the film The English Patient, which was directed by Anthony Minghella, adapts the core of Ondaatje's story, while simultaneously creating a completely new and independent story.

\section{Postmodern theories of adaptation}

Peter Brooker and Gordon Slethaug, critics that directly deal with postmodern adaptations, list terms such as Bakhtin's dialogism, Roland Barthes' death of the author, and Genette's hypertextuality, as the theoretical basis of a postmodern approach to adaptations, which is furthered by Robert Stam, by viewing adaptations as intertextual dialogism, and Linda Hutcheon, by establishing a theory of adaptation as a process and product (Brooker 2007: 107; 112; 113, Slethaug 2014: 3; 4; 5). Namely, Brooker defines adaptations from a postmodern perspective as acts of translation which are "radically heterogenous" and in which the translator is simultaneously an interpreter in the unstable relationship between the writer and the reader, pointing out that such approach destabilizes ideas of equivalence and similarity between former and future texts, and that adaptation is similar to translation as a "hybridizing instance" which is marked by "disparity, gaps, and indeterminacy". Additionally, Brooker, relying on Bertolt Brecht, opposes the stance of Frederic Jameson on the impossibility of discovering anything new in postmodernism, stating that the potential for "originality" is renewed through adaptations by "re-function[ing]" existing narratives or images, by adapting them to a new medium with a renewed "social or artistic purpose". Brooker stresses the ability of the adaptation to radically edit, shift and supplement original texts. He points out that adaptations are always a process of change, and that that process can reverse the chronological order of the source text and adaptation, and if an adaptation remains in a "significant textual contact" with the source text, it will not only change the source, but the understanding and evaluation of the primary text on behalf of the reader (Brooker 2007: 113; 114; 117; 118). In the investigation of the postmodern adaptations, Slethaug relies on the terms "supplementation" and "surplus value", which were coined by Jacques Derrida, on the basis of which it can be viewed how an adaptation and the original work exist in a complex relationship, in which the original does not possess all of the value, and the adaptation is not just 
a diminished version of the original, but holds supplementary values that transcend the original, and because of which the viewer must observe the surplus value of the new work and view the original once more in relation to the changes (2014: 28). Slethaug also asserts that an adaptation is a "citation" repurposed in a new context that does not destroy the meaning of the source text, but "disseminates" it. Namely, an adaptation "exceeds the limits of the source/s, denying hierarchy and suggesting that meaning is indeterminate for both origin and adaptation", while "indeterminacy and de-hierarchization" are crucial aspects of a postmodern approach to adaptations, and as originals cannot control the free play of meaning, this creates the possibility for the free play of textuality. By disregarding the question of fidelity, the slightest surplus value disturbs the meaning of and opens up a dialogue between the original and the adaptation (Slethaug 2014: $28 ; 29 ; 31 ; 34$ ).

\section{The postmodern Canadian novel}

The prevailing characteristics of postmodern literature include temporal disorders, fragmentation and the impossibility of the separation of the text and the world. In postmodern fiction, the order of time is destabilized through apocryphal history, which offers imaginary representations of great historical events, but also through the amalgamation of historical events and personal memories and stories. Through the deconstruction of plot, characters, settings and themes, authors create the fragmentation of text and story so as to circumvent "the wholeness and completion associated with traditional stories", by finding alternative ways of establishing structures of narratives. This rejection of wholeness and the use of fragmentation differentiates postmodernism from the modernist movement. Postmodern texts also disturb the clear difference between texts and reality by introducing known historical figures into a text accompanied by descriptions that clash with realistic representations of such figures or representations of the unknown parts of their lives (Lewis 2001: 124-133).

Hutcheon stresses that the term "postmodernism" refers to art that is self-conscious, i.e., conscious that it is art, as well as referring to literature that is written and read as part of a specific culture and that creates "the means to a new engagement with the social and the historical world" 
(1989: 1). Furthermore, postmodernism is characterized by the exploration of the possibility of establishing order or truth. Postmodern Canadian fiction, which shares these fundamental postmodern tendencies, is also defined by authors that exist on the margins in relation to the cultural center, i.e., on the marginal position that opens up new possibilities and uncovers that borders are not equivalent to limits. Postmodern irony that refuses the resolution of opposites also defines postmodern Canadian authors, who question the relationship between the "structures of social and cultural power" (Hutcheon 1989: 1-10). One of the main forms that the postmodern Canadian novel manifests is "historiographic metafiction". Namely, historiographic metafiction relates to fiction that is "self-reflexively art, but is also grounded in historical, social and political realities", and that represents nontraditional historical novels that are self-conscious in the process of "reading and writing history as well as fiction" (Hutcheon 1989: 13; 14). In such works, art and society, as well as the past and present cannot be separated, and historical facts are not disregarded for the sake of art nor are they used solely to authentically represent fiction, but in them history and art enter into a "critical dialogue". Historiographic metafiction enables the questioning of the causal, linear construction of history as well as metanarratives. Fragmentary representations of stories oppose the completion of history and more accurately represent a meaning of the past that is not unified. Within historiographic metafiction, the reader, who has an active role in the creation of the meaning of the text, confronts history in a "world of imagination" and questions the relationship between fiction and reality (Hutcheon 1989: 14-17). The purpose of historiographic metafiction, the form of postmodern Canadian fiction that also uses conventions of realism by destabilizing the unity of narrative, a reliable point of view and clear characterization, is to question the "human process of writing - of both history and fiction" so as to explore how people come to know and give meaning to history. Much like historiographic metafiction, the works of Michael Ondaatje also exist on the border between history and fiction, as well as poetry and prose (Hutcheon 1989: 21-22). 


\section{The English Patient: novel and film}

Michael Ondaatje's novel, The English Patient, connects the lives of multiple characters:

Count Laszlo de Almásy (the "English" patient); Katherine Clifton, Almásy's married lover; Hana, his nurse; Kip, the kind and gentle Sikh, who falls in love with Hana while serving as a British army lieutenant in a bomb disposal squad; David Caravaggio, Hana's childhood friend and a morphine addict, who carries a personal vendetta against Almásy and who turns up one day at the villa; and Geoffrey Clifton, Katherine's husband. (Costanzo Cahir 2006: 132)

The English patient from the novel, Almásy, who is actually a Hungarian cartographer, and whose character was based on a real-life spy who worked for the Nazi regime in Africa, is only a patient with burn injuries and a memory loss who Hana takes care of in the crumbling villa in Tuscany at the beginning of the novel. The English patient gradually beings to remember his past, his work in northern Africa, his affair with Katherine and the tragic end of that affair (Welsh 2005: 118, 119). Real historical figures of the novel are minor and not immediately recognizable; they serve Ondaatje's reinvention of history by shifting it from the representations based on facts to an understanding of indeterminacy (Novak 2004: 225).

The novel investigates postcolonial themes and "the uncertainty and indeterminacy of identity and nationalism and the extent to which politics constructs selfhood" (Costanzo Cahir 2006: 132). Namely, Ondaatje attempts to rewrite the history of World War II from the perspective of colonized nations in his postmodern novel. Not only is the "re-writing of history a post-modern idea, but the novel itself is written using post-modern strategies" (Morgan 1998: 159). Although none of the main characters in the novel are English, they can all be viewed as "patients of the English" who attempt to discover an identity that is not rooted in colonialism. Aside from the novel's representation of Almásy retrieving his memories so as to reconstruct them in a new history, all the characters face their past and question the war in that conflict with the past, but Kip is the only character who directly questions the problems of colonialism. Kip's story in Ondaatje's novel succeeds in telling the "unspoken", "unwritten" and "unhistorical" stories. By establishing the character of Kip in opposition 
Vera Nikolić: Mapping Memory and Desire in The English Patient: A Postmodern Novel's...

to Almásy, who is based on a real historical figure, Ondaatje's rewriting of history is "polyvocal". Following the fall of the atomic bombs on Hiroshima and Nagasaki, Kip experiences a breakdown due to the conflict of the idea of the English as allies and the English as colonizers, and the focus of the novel shifts from the subject of war to the issue of colonialism. Finally, all the characters gathered in the Tuscan villa, including the English patient, are victims of colonialism, but with Kip's breakdown, Ondaatje gives a voice to the "anger of the colonized" (Morgan 1998: 159-165). The fall of the atomic bombs and Kip's coming to terms with this event shatters the security of the novel's readers and "differentiates the novel as postcolonial and postmodern text from its characters as colonial subjects" (Shin 2017: 225-226).

The failed relationships in the novel between Katherine and Almásy, Katherine and Geoffrey, Caravaggio and Gianetta, Hana and her fiancé, and Hana and Kip, also reflect the "issues of identity and postcolonial theory" (Costanzo Cahir 2006: 132-133). In the novel, Hana and her relationship with Kip is the central point of the novel, while Almásy is attempting to remember his affair that only starts to be revealed around the third of the novel (Welsh 2005: 119). The love between Katherine and Almásy is marked by tropes of fire, that takes and gives life, but also by the desert sand, which is "unstable, ever-shifting, threatening, and mystifying", while the love between Kip and Hana is marked by tropes of art and explosives. Hana is tired as a result of the explosives and the sudden deaths that they bring, while Kip holds a deep knowledge of them and can't help seeing them everywhere. When Kip shows Hana the paintings in an Italian church, he shares with Hana his understanding that humanity is capable of destruction, but also the creation of beauty (Costanzo Cahir 2006: 132134).

Linda Costanzo Cahir describes the narrative structure of the novel, as well as Almásy as a narrator, in the following way:

His narration is intermittent, fragmented, non-linear, and often dream-like. Its qualities define not only Almásy's narration, but the narrative structure of the entire book, also. The novel, which spans seven years, is assembled from ever-shifting, multiple points of view, Almásy's being only one of several consciousnesses that we enter. (2006: 132) 
Not only does Hana take care of Almásy, she also "constructs the story of his wasted life through dim memories" shaped by morphine and the copy of Herodotus that belongs to the patient. Moreover, when Almásy speaks to Hana about his life, his memories are "fragmented and incomplete" (Welsh 2005: 119). The structure of the novel is "dispersed, broken, and divided" because it represents the "multiplicity of stories and of voices" (Morgan 1998: 161). Amy Novak also states that the patient's recollection organizes the narrative of the text, as she quotes The English Patient: "He whispers again, dragging the listening heart of the young nurse beside him to wherever his mind is, into that well of memory he kept plunging into during those months before he died" (Novak 2004: 207). Namely, the memory of the patient serves two purposes in the novel as it provides structure to the discourse of the patient in the story and the narrative as a whole. As Novak asserts: "Memory moves the text forward, draws in the characters around him, and leads to a further unfolding of his own memories and those of the other characters" (2004: 207). Nonetheless, each revelation of the past through memory prompts other memories, and these memories, as well as the fragments of images and sentences that comprise these memories, resist linearization and do not offer a clear representation of the past (Novak 2004: 207). Such a narrative of the past that consists of "fragmentary memories" shows that the relationship between the present and the past is not rooted in causation, but reflects that the past is incomplete and that the past and the present can permeate one another, and that the meaning results from the "play of signification" that is constantly shifting. The quickening transitions from the past to the present and from the present to the past in The English Patient show how fragmentary memories supplement the present with a moment from the past or the past with the present, while the meaning of the past or present stems from this process of supplementation (Novak 2004: 208209). A narrative organized on the basis of the "dynamics of memory" that drags the past into the dimension of the present with fragmentary memories does not establish linear or causal relationships between events, reflects the ambiguity of the past and negates the attempt at "constructing a cohesive singular narrative of the past" through the representation of memory (Novak 2004: 211; 225; 226). Although every character of The English Patient attempts to create a complete representation of their past, the fragmentary nature of memory and the ghosts that cannot be contained in their pasts reject the possibility of a clear organization of the narrative. 
Vera Nikolić: Mapping Memory and Desire in The English Patient: A Postmodern Novel's...

This "narrative scheme" of every character's story organizes the whole novel, which is continually "exploring how we understand and narrate the past", as well as exploring how we understand traumatic events such as nuclear explosions (Novak 2004: 220). Almásy's exploration of the desert and the past is also connected to his desire for truth, but his attempt to establish order in the instability of the present and the past is unsuccessful, as the narrative of memory prevents the connection of the events that have occurred (Novak 2004: 216-217). Finally, as Costanzo Cahir illuminates: "Ondaatje's use of maps, geography, and cartography work as metaphors for people, for their particular contours, and for our need to explore and to know - to map - the intricate terrain of those we love" (2006: 132).

Costanzo Cahir classifies the adaptation of The English Patient as a traditional translation as it transfers the key meanings of Ondaatje's text, since the director and screenwriter Anthony Minghella creates "the equivalents of Ondaatje's fragmentation" (2006: 134) with a narrative that goes back into the past and returns to the present, by breaking up the story and using nonlinear narration, which encompasses multiple points of view. Namely, Minghella's use of nonlinear structure mirrors Ondaatje's ideas that memory cannot be coherently organized (Costanzo Cahir 2006: 134-135). Conversely, James Welsh asserts that the narrative of the film is not completely organized nonlinearly because even though the "epic love story" is represented with flashbacks, they are organized chronologically. Additionally, while Minghella maintained the basis of the novel such as the characters, settings and themes, the characters of Hana and Kip, their love affair, as well as the character of Caravaggio, are minimized in the film and reduced to a framing story, while the focus is placed on the relationship between Almásy and Katherine (Welsh 2005: 119). The film romanticizes the character of Almásy, thus distancing itself from the novel, that does not fully resolve the patient's cooperation with the Nazis, while the film clearly represents that cooperation as morally motivated in order for Almásy to save Katherine (Welsh 2005: 119, Costanzo Cahir 2006: 135). Nevertheless, Ondaatje noted about the adaptation of The English Patient that: "What we have now are two stories... Each has its own organic structure... but somehow each version deepens the other" (Welsh 2005: 119). The film, which shifts from the realistic to the dreamlike, from the past to the present, and from one pair of lovers to the other, succeeds in telling "its story largely through visual images, rather than through dialogue taken from the novel", thus establishing the lyrical style 
of the novel within the cinematic medium. Some of the most recognizable images of the film include the scene of Hana and Kip in the Italian church, the Cave of Swimmers, as well as the image of Almásy carrying Katherine's body wrapped in a silk parachute (Costanzo Cahir 2006: 137). Minghella, who was motivated to adapt the novel so as to "articulate the passion" between Katherine and Almásy, successfully realized the love story of the novel, but in doing so, he also marginalized Kip and distanced himself from the exploration of the postcolonial problems of the novel. The past and the memories of Kip, Hana and Caravaggio that were presented in the novel, are lost in the film, which only presents Almásy's past in Cairo and in the desert, and whose only narrating voice is Almásy's voice. Consequently, the film "denies the other characters the right to history" and "reduces Ondaatje's polyvocal novel into a univocal narrative" (Morgan 1998: 165). One of the biggest changes of the film that neglects the problematization of colonialism depicted in the novel is the removal of Kip's reaction to the fall of atomic bombs, which affects his motivation to leave Hana. In contrast to this, the film shows how Kip leaves Hana out of love so as to protect her from the suffering she would feel in the case of his death on duty (Morgan 1998: 164-166). The replacement of the political conflict stemming from the fall of the atomic bombs with the death of the character of Hardy, the film adaptation switches the focus of the novel from postcolonial issues to a love story (Hutcheon 2006: 12). By placing the focus of the film on the two white protagonists of the film united in death, instead of placing it on the relationship between Hana and Kip that ultimately ends, the political perspective of history that is established in the novel is removed, replaced by the prevailing message of a love worthy of loss. Without Kip's conflict resulting from the atomic bombs, he does not come to an awareness of "racial hierarchies" and his own culture, but the story ends with a narrative of friendship and love. Moreover, in the end of the film Hana becomes a "conduit between the past and the present", while the film ends with a scene in which Almásy and Katherine fly over the desert, depicting an "image of transcendence" over the past and history (Shin 2017: 225; 228; 229; 230; 231).

Despite focusing on the relationship between Almásy and Katherine instead of the relationship between Hana and Kip, these characters "embody and enact desires that transgress both national and familial boundaries" (Hsu 2005: 50) in the film that functions as a "post-national romance" that uses "extra-marital bonds as metaphors for international alliances" (Hsu 
Vera Nikolić: Mapping Memory and Desire in The English Patient: A Postmodern Novel's...

2005: 50). That desire transpires among the couples, when Kip shows Hana frescoes in a church, or in a scene where Hana feeds Almásy a plum, and leads the characters to "unsanctioned pleasures". Minghella also visually connects the depictions of bodies with landscapes with an initial scene that depicts the painting of bodies followed by a shot of the desert resembling a body. By engaging in extramarital relationships, the characters of the film abandon the boundaries of desire defined by marriage, in the same way that maps represent the boundaries of nations, although these attempts and desires to transcend "social and national boundaries" mostly fail. The depictions of transgressive desires include the abovementioned scenes with the plum and the shot of the desert resembling a body, as well as Hana's love for Almásy, Kip's love for Hardy, and Maddox's love for the desert. Although these "lines of flight" are mostly unsuccessful, Kip and Hana succeed in transcending the boundaries of sexuality and nationality (Hsu 2005: 50-55). Kip moves across these borders by disposing of bombs and "removes potentially violent traces of imperialism", thus enabling desires to not be limited by imperialism, war or maps (Hsu 2005: 55). In contrast to Katherine, who dies immobile in the dark, Hana crosses the boundaries in the "surrogate love scene" in the church, and by surrendering to desire, she enters an active role of an observer and lights up the frescoes around herself, thus transgressing the borders that surround her (Hsu 2005: 50; 55 ; 56; 59).

The remaining transgressions of borders are established with the use of flashbacks. Namely, flashbacks that follow the scenes in which Hana reads texts and that show Katherine reading or writing these texts in the past, while their voices are heard one after the other, transition the film from one story to another, enabling Hana to integrate Almásy's traumatic past into her memory. The transitions from one space and time into another space and time i.e., from Africa in 1939 into Italy in 1945, enable the viewers themselves to transgress boundaries. The ending of Minghella's The English Patient represents a total dissolution of boundaries by connecting the voice of Katherine with the voice of Hana, by connecting the song, which is first heard when Hana plays it on the piano, with Almásy's Hungarian song, which he plays to Katherine during the film, while Hana leaves the villa in Tuscany "riding in a truck, staring at the sun in tears" (Hsu 2005: 58-60).

Finally, some of the issues presented in the novel are transferred in the film, especially the questioning of the issue of national relations affecting the relationships of individuals, with a focus on the ideas of 
counter-nationalism. These ideas are reflected in the film, when Katherine advocates that the relationships of individuals should transcend nations, and when Kip leaves Hana in the film because of his feelings for her, and not because she comes from a country that is a former colonial power. The film also manages to impart the idea that art can "transcend borders and nationalities", as the songs and sounds heard during the film, melt into one another, like the Hungarian folk song melting into the sound of a prayer, while later on the music of Bach merges with the Hungarian folk song. Hana also confesses to Kip that she would continue to return to the church to look at the paintings that she saw with Kip, showing how Hana and Kip achieve unity through art (Morgan 1998:167-171).

\section{Conclusion}

Viewing adaptations from a distinctly postmodern perspective recognizes that they can be characterized by instability in meaning, oppose similarity and uphold indeterminacy. The refunctioning of narratives that occurs through adaptations allows for a new way of discovering originality enabled by radical shifts from the initial meaning found in texts, while the creation of new texts in relation to old ones creates surplus value, thus establishing a process of supplementation between texts.

The process of supplementation is evident in the adaptation of the novel The English Patient, which is marked by postmodern characteristics such as fragmentation and the disordering of the past and present, thus rejecting the wholeness and completion of more traditional narratives. The novel also remains reflexive of the history within which it is written, while it places art and history in a critical dialogue and questions the relationship between the past and the present in an act of re-writing the history of World War II. The English Patient has a fragmented narration, which revolves around an attempt of retrieving memory, and a dispersed structure containing multiple perspectives, and ultimately examines the issues of colonialism, while showing how history resists linearization. The film The English Patient transfers the novel's fragmentation, while shifting the narrative's primary focus, which becomes the love affair between the characters of Katherine and Almásy, and relegating the remaining characters to the framing story of this love affair. These changes distance the film from the novel's postcolonial critique and its resistance to the possibility of 
Vera Nikolić: Mapping Memory and Desire in The English Patient: A Postmodern Novel's...

constructing a coherent image of the past, but are accompanied by the film's visual prowess, in a rich and lyrical presentation of the novel's story. Thus, the cinematic adaptation of the novel The English Patient reinterprets and recreates the original work into a new text using processes of transformation of the story and plot. The new story is simultaneously marked by similarity and difference, and the fragmentation and nonlinearity of the novel are transferred, but also altered together with the shift of the film's focus in relation to the literary story. Based on this, the narrative of the memory of multiple characters in a/the novel filled with desire, becomes, in the film, a narrative of desire, which is found in the memories of one character, while the story of the novel The English Patient does not end with the novel, but continues in the film.

Finally, the adaptation shows how an intentional and radical process of innovation of an original text led by a renewed artistic purpose, promotes the free-play of textuality and how the recognition of the relationship between the meaning of texts, and a surrender to the indeterminacy of meaning allows for textual supplementation and the unobstructed creation of surplus value. With an understanding of supplementation, radical transformations and the diversity of textual relations, the adaptation of the postmodern novel The English Patient into a film can be appreciated for its surplus value and remain unburdened by evaluations of its faithfulness.

\section{References}

Brooker, P. (2007). Postmodern Adaptation: Pastiche, Intertextuality and Re-functioning. In: D. Cartmell and I. Whelehan (eds.), The Cambridge Companion to Literature on Screen, Cambridge/New York: Cambridge University Press, 107-120.

Costanzo Cahir, L. (2006). Literature into Film: Theory and Practical Approaches. Jefferson, North Carolina: McFarland \& Company.

Hutcheon. L. (1989). The Canadian Postmodern: A Study of Contemporary English-Canadian Fiction. Oxford: Oxford University Press.

Hutcheon, L. (2006). A Theory of Adaptation. New York/London: Routledge. Hsu, H. (2005). Post-Nationalism and the Cinematic Apparatus in Minghella's Adaptation of Ondaatje's The English Patient. In: S. Tötösy de Zepetnek (ed.), Comparative Cultural Studies and Michael Ondaatje's Writing, West Lafayette, Indiana: Purdue University Press, 49-61. 
Lewis, B. (2001). Postmodernism and Literature. In: S. Sim (ed.), The Routledge Companion to Postmodernism, New York/London: Routledge, 121-133.

Morgan, M. (1998). The English Patient: From Fiction to Reel. Alif: Journal of Comparative Poetics, No. 18, 159-173.

Novak, A. (2004). Textual Hauntings: Narrating History, Memory, and Silence in "The English Patient". Studies in the Novel, Vol. 36, no. 2, 206-231.

Slethaug, G. (2014). Adaptation Theory and Criticism: Postmodern Literature and Cinema in the USA. New York/London: Bloomsbury.

Shin, A. (2007). The English Patient's Desert Dream. Lit: Literature Interpretation Theory, Vol. 18, No. 3, 213-235.

Welsh, J. (2005). The English Patient. In: J. Tibbetts and J. Welsh (eds.), The Encyclopedia of Novels Into Film, New York: Facts on File, Inc., 118-119.

\section{Bibliography}

Minghella, A. (1996) The English Patient. Tiger Moth Productions.

Ондачи, М. (1997). Енглески пацијент. (Ивана Дамјановић, прев.). Београд: Народна књига.

Received: 28 September 2021

Accepted for publication: 02 November 2021 